\title{
Managing Tourism Sector in Nigeria through Privatization Strategy
}

\author{
Emmanuel I. Akpan (Ph.D.) \\ Department of Business Management \\ University of Calabar \\ P.M.B. 1115, Calabar, Nigeria \\ Tel: 234-80-3723-0541Ｅ-mail: drisaiahakpan@yahoo.com
}

Received: January 21, 2012

Accepted: February 18, 2012

Online Published: June 15, 2012

doi:10.5430/bmr.v1n2p120

URL: http://dx.doi.org/10.5430/bmr.v1n2p120

\begin{abstract}
Petroleum sector constitutes the mainstay of Nigerian economy. The risk potentials of this condition need not be overstressed. The recognition of positive impacts of tourism on economic development made Nigerian government to commit resources towards diversifying the economy through tourism development. The level of benefit so far derived from the sector does not justify the volume of investment because government plays domineering role in this sector management. Tourism development could rather be achieved if the "public administration" style currently adopted is replaced with collaborative approach, herein referred to as "partial privatization". This approach prescribes government-private sector management process. By this strategy, each party would better understand its roles and responsibilities in the management of the sector; significant degree of prudence and probity would be demonstrated; tourist's needs would effectively be identified and satisfied; the sector would become attractive, viable and sustained.
\end{abstract}

Keywords: Managing, Tourism, Privatization, Strategy, Nigeria

\section{Introduction}

Business in petroleum sector, to a large extent, constitutes the fulcrum of Nigerian economy, a condition that is obviously perilous. Having recognized barrage of negative consequences of mono-faceted economy such as this, Nigerian government at various tiers, over the years, deliberated on how to diversity the nation's economy, in order to fast-track general development. So far, investments in agricultural and entrepreneurial endeavors have yielded insignificant support ratio to the country's economic growth-drive.

Like many other countries, Nigeria has come to realize the potential benefits in adopting tourism as a viable option of diversifying the nation's economy. This fact could be stressed through the level of investments so far made in the sector by the federal and some state governments.

It is imperative to note at this juncture that the level of success in terms of accomplishing the goal of economy diversification through tourism development is a function of the way the sector is managed. In other words, should the sector be run entirely by government (with public enterprise management style) or in collaboration with selected private investors (partially privatized) or the sector entirely left for the private investors (absolutely privatized).

Tourism venture, in its global context, is relatively new in Nigeria. It is an innovation likened to a product within the introduction stage in its life cycle. In this paper, tourism and privatization ipso facto constitutes the major concepts under review and upon which reasonable analysis and conclusions were based.

\section{Theoretical framework}

Tourism is a social activity that involves travel by individual or group, to stay outside their usual environment for a period, in most cases not above one year, for purposes of satisfying leisure, business or other needs. It could be looked at as a business entity that provides places and events to occupy people while they are on holidays (Agba, Ikoh, Bassey and Ushie, 2010). According to Menthose \& Cupa (1980), as cited in Egbaji (2007), tourism means the science, art and business of attracting and transporting visitors, accommodating them and graciously catering for their needs and wants. Tourism is facilitated by certain specific activities. This fact supports the dictum of Akpet (2005), cited in Eja, Otu, Ewa \& Ndoma (2011) that tourism is all embracing and involves the interaction of other components such as transportation, communication, accommodation and destination amongst others. 


\subsection{Sustainable tourism development (STD)}

Several countries strive to maintain sustainable tourism development within their domains to enable them accomplish an avalanche of benefits. Sustainable tourism development could be viewed as tourism which is developed and maintained in an area (community, environment) in such a manner and at such a scale that it remains viable over an indefinite period and does not degrade or alter the environment (human and physical) in which it exists to such a degree that it prohibits the successful development and well-being of other activities and processes (Tosun, 2001). According to him, that is not the same as sustainable tourism which is in a form which can maintain its viability in an area for an indefinite period of time.

\subsubsection{Principles of sustainable tourism development}

According to Tosun (2001), the principles of tourism development include the following:

- STD should contribute to the satisfaction of basic and felt needs of those hitherto excluded in local tourism destinations.

- It should reduce inequality and absolute poverty in local tourist destinations.

- It should contribute to the emergence of necessary conditions in tourist destinations which will lead local people to gain self-esteem and to feel free from the evils of want; ignorance and squalor.

- It should accelerate not only national economic growth, but also regional or local economic growth. The growth must be shared fairly across the social spectrum.

Sustainable tourism development should achieve the above objectives or principles in an indefinite period of time without compromising the ability of future generations to meet their own needs.

\subsection{Importance of Tourism sector}

Tourism venture has been found to be of utmost social and economic importance to many countries. Tourism contributes substantially to a country's gross national products (GNP). According to WTO (1999), tourism sector produces $4.4 \%$ of the total GDP. It also contributes to the overall economic development through the provisions of roads, communication, treated water, sewage treatment. WTT (2010) estimates show that in 2002, travel, tourism and related activities contributed $11 \%$ of the world's GDP, rising to $12 \%$ by 2010 . Tourism also promotes bilateral, multilateral and sub regional co-operation among countries and states.

Tourism is a major employer of labor in the world. Over 600 million people travel internationally. Hundreds of millions more people embark on journey within their home countries, doing so for both work and pleasure. As a result, the tourism industry, including hotels, resorts, airlines, travel agencies and other businesses that cater for travelers is seen as the world's major employer of labor.

Sustainable tourism can be effective instrument for realizing the Millenium development goals (WTO, 2006). Makame \$ Boom (2008) see tourism as a strategy for achieving poverty alleviation goal, providing sustainable development opportunities to isolated poor communities even in the most remote rural areas. According to ESCAP (2001), tourism can be an effective tool for sustainable development, contribute to poverty alleviation and help conserve the natural and cultural environment.

Socially, tourism has a great influence on the host societies. It can be both a source of international amity, peace and understanding.

The importance of tourism cannot be overemphasized. UNWTO (2001) clearly shows the vitality of tourism for many countries, such as France, Egypt, Greece, Lebanon, Isreal, United States, United Kingdom, Spain, Italy, and Thailand, and many island nations, such as the Bahamas, Fiji, Maldives, Philippines and the Seychelles: it brings in large amount of income in payment for goods and services and create opportunities for employment in the services industries associated with tourism. The general importance of tourism can further be denoted through country's expenditure ranking reports of the World Tourism Organization for the year 2010, as presented in table 1 .

Based on the significant, positive impacts of tourism in several economies, and the drive by many countries and Nigeria in particular, diversification efforts have been made regarding how the sector could be developed and sustained. In an attempt to find solution to this, some authors prescribed near "public administration" approach in the overall planning and management of tourism. Australia glaringly adopts this approach. In this country, government plays the role and assumes the responsibilities for the general planning and management of tourism. In Australia's federal system, commonwealth, state/tertiary and local governments share roles and responsibilities for tourism planning and policy development (Dredge, Macbeth, Carson, Beaumont, Northcote \& Richards, 2006). 
In Nigeria, tourism management in terms of planning and policy development is the government's sole responsibility, distinctively performed by either the federal or state government without serious collaboration. This paper prescribes the application of collaborative approach that embraces the government and the private sectors in the entire management process. This approach, in the context of this paper is described as "partial privatization".

\subsection{Privatization Concept}

Privatization implies permanent transfer of control, as a consequence of transfer of ownership right, from the public to the private sector (Jerome, 2008). According to Akpan (2004), privatization refers to the process by which government transfers (by sale) a part of, or the entire equity of a public establishment to private investor(s), such that the ultimate control of the organization shifts partially or absolutely from the government or any of its agencies to private hands. The concept simply means the sale of state-owned enterprises to private investors (Hill, 2005).

Privatization could either be complete (absolute) or partial. In the case of absolute privatization, the whole share ownership and management are transferred to private sector, while partial privatization entails joint share ownership and management by government and the private investors.

When the government transfers part of its equity volume to the private sector, it means proportionate power or authority is ceded to the investors. Therefore, partial privatization is a management approach which gives both the government and the private investors the opportunity to take part in the management process.

\subsubsection{Reasons for adoption of privatization}

According to Black (2002), the reason for the adoption of privatization includes; reducing the power of central authorities; raising revenue for the government, and spreading property ownership more widely in society. The desire for increased efficiency has also been said to support the rationale behind the adoption of privatization, such as the case of British Airways and British Telecom in the United Kingdom (Kotler \& Keller, 2009). Adoption of privatization is also attributable to widespread failure of state-run enterprises and mounting government debts around the world (Eun \& Resnick, 2007).

\subsubsection{Pros and cons of privatization}

The benefits of privatization are many. In Mexico, for example, privatization of the national telephone company resulted in almost immediate benefits when the government received hundreds of millions of dollars of much needed capital from the sale and immediate investment in new telecommunications systems. A similar scenario has been noticed in Brazil, Argentina, India and many eastern European countries (Cateora, Graham \& Salwan, 2010). Adogba (2008) added that privatization reduce government bureaucracy, reduce state monopolies and ensure level playing fields, reduce bad management, correct defective capital and financial structures, increase competitiveness, increase the quality of goods and services, reduce corruption and control by government, increase staff quality and supervision, free up government funds for more pressing problems, create employment, attract foreign investments, redistribute wealth, etc.

According to him privatization has been engulfed with complex problems with each country having its own peculiar solutions. These problems include; private firms concentrate on profit making to the detriment of essential public service, private firms render more expensive services, they fail to invest in infrastructure, reduction of public workforce and experience, they are interested in short term benefits, they find it difficult to render public services, it reduces public accountability etc.

Problems from privatization vary with countries, coupled with the problem solving models adopted by them.

\section{Managing the Nigerian tourism sector through partial privatization and potential benefits of that strategy}

The Nigerian tourism sector, if partially privatized, would be managed by relevant board comprising appropriate government agency and the representatives drawn from the private sector.

Each of the parties apart from making inputs regarding objective setting, policy development, resources acquisition and utilization, strategy formulation, would have specific roles to play in the general management of the sector.

The powers and authorities vested in the parties would depend on the constitution (or act of the parliament) that governs the operations of the industry.

The management behavior of this kind of structure would exhibit both public and private interests, and enhance effective satisfaction of social goals and maximization of investment returns.

The private sector participation in the management structure would foster greater commitment towards quality product or service delivery, for tourists' satisfaction and patronage in order to maximize investment returns. 
The private investors ordinarily are closer to the grassroot. Therefore, their participation in the management of the tourism industry in the country would facilitate easy identification of relevant stakeholders in the society, such as individuals, communities, groups (e.g. NGO's, youth and cultural organizations etc) with valuable potentials in the promotion and development of the sector.

Partial privatization of this sector would facilitate faster development and utilization of abundant sites with tourism potentials and characteristics, which are currently either abandoned or underutilized. With this management approach, private investors (or in partnership with government) would be encouraged to effectively bring such destinations into operations.

The burden of managing tourism industry by government alone would be greatly minimized through this structure, such that reasonable attention could be paid to education, health, infrastructure. Government would also pay adequate attention to the establishment of regulatory framework, through which the private investor's operations could be monitored and stream-lined.

The division of tasks and responsibilities between the parties involved in the management could lead to effective performance, operational efficiency and increased profit generation in the industry.

The profit-oriented private partners would be more prudent in these operations so as to achieve increased dividend and boost revenue level of the government.

Role specification practicable in this context would lead to exhibition of reasonable degree of accountability and probity by the parties in the sector management.

\section{Conclusion}

For more than three decades, Nigerian economy has been depending majorly on petroleum sector for revenue generation. The risk associated with this type of economic condition has in recent years made federal government to consider tourism development a sine qua non in an attempt to diversify the economy and fast track general development.

So far, the federal government, as well as some state governments has committed many resources to the development of this sector, having witnessed an avalanche of benefits enjoyed by several other countries.

One of the major challenges facing government in trying to bring about sustainable tourism development is in the area of determining effective management structure or approach applicable in the sector.

The public administration approach currently adopted by government is incapable of yielding the envisaged goal.

Partial privatization which allows the government and the private investors participate in the process of managing the sector would constitute effective approach for achieving sustainable tourism development especially at this early (introduction) stage in Nigeria.

\section{References}

Adogba, O. (2008). Critical appraisal of privatization in Nigeria. Lagos: Brook chambers. (chapter 1).

Agba, O. A., Ikoh, M. U., Bassey, A. O. \& Ushie, E. M. (2010). Tourism industry impact on Efiks culture. International Journal of Culture, Tourism and Hospitability Research. 3 (4). 21-28.

Akpan, E. I. (2004). Privatization and national development. Multidisciplinary Journal of Research Development. Benue State University. 3 (1). 65-73.

Black, J. (2002). Oxford dictionary of economics. ( $2^{\text {nd }}$ ed.). New York: Oxford University press.

Cateora, P. R., Graham, J. L. \& Salwan, P. (2010). (13 ${ }^{\text {th }}$ ed.). New Delhi: McGraw-Hill. (Chapter 6).

Dredger, D., Macbeth, J., Carson, D., Beaumont, N., Northcote, J. \& Richard, F. (2006). Achieving sustainable tourism management. [Online] Available: http://www.crctourism.com.au. (January 4, 2012).

Egbaji, S. (2007). Tourism development in Nigeria. The Cross River State experience. ( $1^{\text {st }}$ ed.). Lagos: Elshappire Limited. (Chapter 1).

Eja, E. I., Otu, J. E., Ewa, E. E. and Ndomah, B. (2011). The role of private sector participation in sustainable development in Cross River State, Nigeria. International Journal of Business and Social Science. 2 (2). 10-16.

ESCAP Tourism Review. (2001). Managing sustainable tourism development. Bangkok: United Nation's publication. 
Eun, C. S. \& Resrick, B.G. (2007). International financial management. ( $4^{\text {th }}$ ed.). Boston: McGraw Hill Irwin. (Chapter 16).

Hill, C.W.L. (2005). International business competing in the global market place. (5 ${ }^{\text {th }}$ ed.). New York: Mc Graw-Hill/Irwin Publication, (Chapter 2).

Jerome, A. (2008). Privatization and enterprise performance in Nigeria: Case study of some privatized enterprises. Nairobi: Modern Lithographic (k) Ltd. (Chapter 2).

Kotler, P. \& Keller, K. L. (2009). Marketing Management. (13 ${ }^{\text {th }}$ ed.). New Jersey: Pearson Prentice-Hall. (Chapter $1)$.

Makame, M. K. and Boon, E. K. (2008). Sustainable tourism and benefit sharing in Zanzibar: the case of kurengwa-Pongwe Forest Reserve. 24 (2), 1-15.

Tosun, C. (2001). Challenges of sustainable tourism development in the developing world: the case of Turkey. Tourism Management, 22 (3), 289-303. http://dx.doi.org/10.1016/S0261-5177(00)00060-1

UNWTO. (2011). World tourism barometer. [Online] Available: http://unwto.org/state/eng/pdf/barometer/unwto_barom09-2-en-excerptpdf. (October 12, 2011).

WTO. (2006). Tourism: A key resource for sustainable economic and social development. [Online] Available: http://www.worldtourism.org/newsroom/releases/2006/september/think-tank.htm. Retrieved June 11, 2011.

WTTC. (2010). The impact of travel and tourism on jobs and economy. [Online] Available: http://www.wttc.org. (April 10, 2011).

Table 1. International Tourism Expenditures using top ten biggest spenders (countries) for the year 2010

\begin{tabular}{|l|l|l|l|}
\hline Rank & Country & UNWTO Regional Market & International Tourism Expenditures (2010) \\
\hline 1 & Germany & Europe & \$77.7 billion \\
\hline 2 & United States & North America & \$75.5 billion \\
\hline 3 & China & Asia & \$54.9 billion \\
\hline 4 & United Kingdom & Europe & \$48.6 billion \\
\hline 5 & France & Europe & \$39.4 billion \\
\hline 6 & Canada & North America & \$29.5 billion \\
\hline 7 & Japan & Asia & \$27.9 billion \\
\hline 8 & Italy & Europe & \$27.1 billion \\
\hline 9 & Russia & Europe & \$26.5 billion \\
\hline 10 & Australia & Oceania & \$22.5 billion \\
\hline
\end{tabular}

\section{Source: UNTWO (2011).}

